\title{
Geochemical characterization of karst groundwater in the cradle of humankind world heritage site, South Africa
}

\author{
M. Holland · K. T. Witthüser
}

Received: 7 March 2008/Accepted: 3 April 2008/Published online: 3 June 2008

(C) The Author(s) 2008

\begin{abstract}
The karst of the Cradle of Humankind World Heritage Site plays a major role in the assimilation or carrying of acid mine drainage, sewage effluent return flow and agricultural run-off. Infiltration of contaminated water has altered the chemical composition of the natural waters of the karst system. A multivariate statistical method in combination with conventional geochemical and spatial analysis was applied on groundwater and surface water quality samples to determine the spatial extent of hydrochemical impacts from different anthropogenic sources. The application of hierarchical cluster analysis of the major ions (148 samples) recognised three distinct hydrochemical regimes. Cluster 1 is moderately mineralized, especially with regard to chloride, nitrate and sulphate, cluster 2 has a low mineralization with all elements well within the recommended drinking water limits of South Africa and cluster 3 represents highly mineralized samples taken in the vicinity of decanting mineshafts. The cluster solution is confirmed by a simple mixing model, indicating varying contributions of three identified end members (acid mine drainage, treated sewage effluents and pristine dolomitic groundwater) to the groundwater quality in the catchment. The combination of statistical, geochemical and spatial methods in conjunction with end-member mixing analysis provides a reliable method to understand the processes
\end{abstract}

\footnotetext{
M. Holland ( $\square)$

Department of Geology, University of Pretoria,

Pretoria, South Africa

e-mail: m.holland@mweb.co.za

K. T. Witthüser

Department of Geology, University of Pretoria,

Pretoria, South Africa

e-mail: ktw@up.ac.za
}

responsible for the groundwater quality variations and to assist in the identification of anthropogenic impacts.

Keywords Karst · Geochemistry · Multivariate statistics · Acid mine drainage

\section{Introduction}

The Cradle of Humankind World Heritage Site (COHWHS) is mostly underlain by the karstified dolomites of the Chuniespoort group (Transvaal supergroup). The dolomites are a vital component of the water resources needed for the expanding demand of the urban complexes in Gauteng; hence, it is considered as one of the most important aquifers in South Africa (Barnard 2000). Despite its importance, ongoing exploitation of the resource along with past gold mining activities has resulted in the deterioration of the resource quality (Holland 2007; Hobbs and Cobbing 2007). The high transmissivity associated with dissolutional voids in the karst aquifers allow contaminant inputs to spread quickly and affect large bodies of the fresh water resource. The objective of this study is to determine the extent of different anthropogenic impacts on the karst groundwater in the COHWHS catchment. The use of isotopic data is the preferred and well-established method of choice to trace ground-water flow (e.g. Glynn and Plummer 2005). However, in the absence of isotopic data, a detailed interpretation of major and trace elements can also achieve a good understanding of the flow system if sufficient variability in hydrochemistry is found. In anthropogenically impacted environments, pollution sources have typically characteristic chemical signatures with selected element concentrations clearly elevated beyond their natural variability. Sewage works, for example, are likely to be associated with high 
BOD, COD and elevated concentrations of nitrate, phosphate, organic chemicals, E. coli and other bacteria in groundwater (Love et al. 2004). On the other hand, highly mineralized acidic water with high sulphate/chloride ratios can be attributed to mine drainage (AMD) in the absence of gypsum bearing strata. Agricultural run-off signatures are generally represented by common constituents of fertilisers or livestock excrements (e.g. potassium, ammonium and nitrate, E. coli and possibly other bacteria). The use of major ions and trace elements as natural tracers for anthropogenic signatures has therefore become a common method to delineate the spatial influence of anthropogenic sources on water resources (Helena et al. 2000; Lambrakis et al. 2004; Thyne et al. 2004). Assessments of hydrochemical processes in groundwater systems are typically aided by conventional geochemical displays (e.g. histograms, Piper plots) and multivariate statistical methods (Guler et al. 2002; Hussein 2004; McNeil et al. 2005; Singh et al. 2004). While graphical techniques provide valuable and rapidly accessible information, they visualize only a limited number of variables and are not particularly useful to produce distinct groups of samples discriminated by objective means (Guler et al. 2002). On the other hand, multivariate methods like cluster analysis can compare and objectively classify different water samples based on the full range of chemical parameters of the water analysis. The samples are divided into groups of similar hydrochemical signatures, which can eventually be spatially correlated (Güler et al. 2002). Combining these two approaches with an end-member mixing analysis (EMMA) between the identified end-members of the groups provides a higher confidence in an otherwise purely statistical assessment. EMMA is used to estimate the contributions of known or hypothetical source solutions to the chemistry measured at a point of discharge (Doctor et al. 2006). This paper intends to use this combination of methods for a qualitative and quantitative description of the geochemistry of the COHWHS karst catchment. In return this method provides and improved understanding of the sources and factors controlling groundwater quality including discriminating natural background and anthropogenic impact. Although numerous studies have documented the general impacts of anthropogenic activities on the groundwater chemistry in the area (Van Biljon 2006; Hobbs and Cobbing 2007), no systematic interpretation thereof has been made to date.

\section{Site description}

\section{Study area}

The Cradle of Humankind is located approximately $40 \mathrm{~km}$ northwest of Johannesburg, South Africa (Fig. 1), and is deemed a World Heritage Site mainly due to its vast treasure chest of fossilized remains of past life forms, particularly hominids found in the karst caves of the Malmani Dolomite.

The COHWHS has received great attention since the first mine water started to decant south of the area near Krugersdorp in August 2002. The gold-bearing reefs of the Witwatersrand basin have been mined since 1887. During this period, water was pumped from the mine workings to enable deeper mining to take place. As the gold content in the reef declined more gold mines closed, resulting in dewatering operations being ceased. The rebounding water table has led to significant pollution of groundwater in the abandoned mining areas by acid mine drainage (AMD). AMD is a result of the oxidation of metal sulphides, and is characterised by elevated heavy metal concentrations, high sulphate contents, an increased electrical conductivity and a lowering of the $\mathrm{pH}$ of the water in the mining area (Heikkinen et al. 2002; Williams and Smith 2000).

In addition to the mining activities, two wastewater treatment plants (municipal sewage works) and numerous agricultural smallholdings are located in the catchment. The tributaries of the catchment play therefore a major role in assimilating the mining, industrial and municipal wastewater together with run-off from agricultural land. These surface waters enter the karst aquifer through swallow holes, dolines and diffuse leakage from riverbeds. Such inflows are characteristic of karst terrains (Wang et al. 2001) and pose a threat to the water resources in the area.

\section{Geological setting}

The north-western boundary of the COHWHS follows the ridge underlain by the quartzite of the Timeball Hill formation (Pretoria group). The south-eastern boundary transects the western part of the granitic Johannesburg dome and neighbouring ridges of gold-bearing Witwatersrand formations, forming the faulted rim of the Witwatersrand basin. Towards the west of the Johannesburg dome the basal formation of the Transvaal supergroup outcrops, consisting of the quartzitic Black Reef formation, which underlies the Malmani dolomite subgroup (Fig. 1). The Malmani dolomite rocks were formed in an early Proterozoic shallow epeiric sea (Clendennin 1989), and consist essentially of shallow marine stromatolitic dolostone and have been subdivided into five formations of alternating chert-poor and chert-rich dolomite. Karstification has been more active in the chert-rich dolomite, due to higher porosity being developed in the brittle fragmented, and cherty horizons being accessed by deeper penetrating fractures and fissures. Therefore, the chert-rich dolomite has generally good water-bearing and storage characteristics (Bredenkamp et al. 1986). The karst of the Malmani subgroup is an important example of a karst developed on a 
Fig. 1 Locality and regional geology of study area

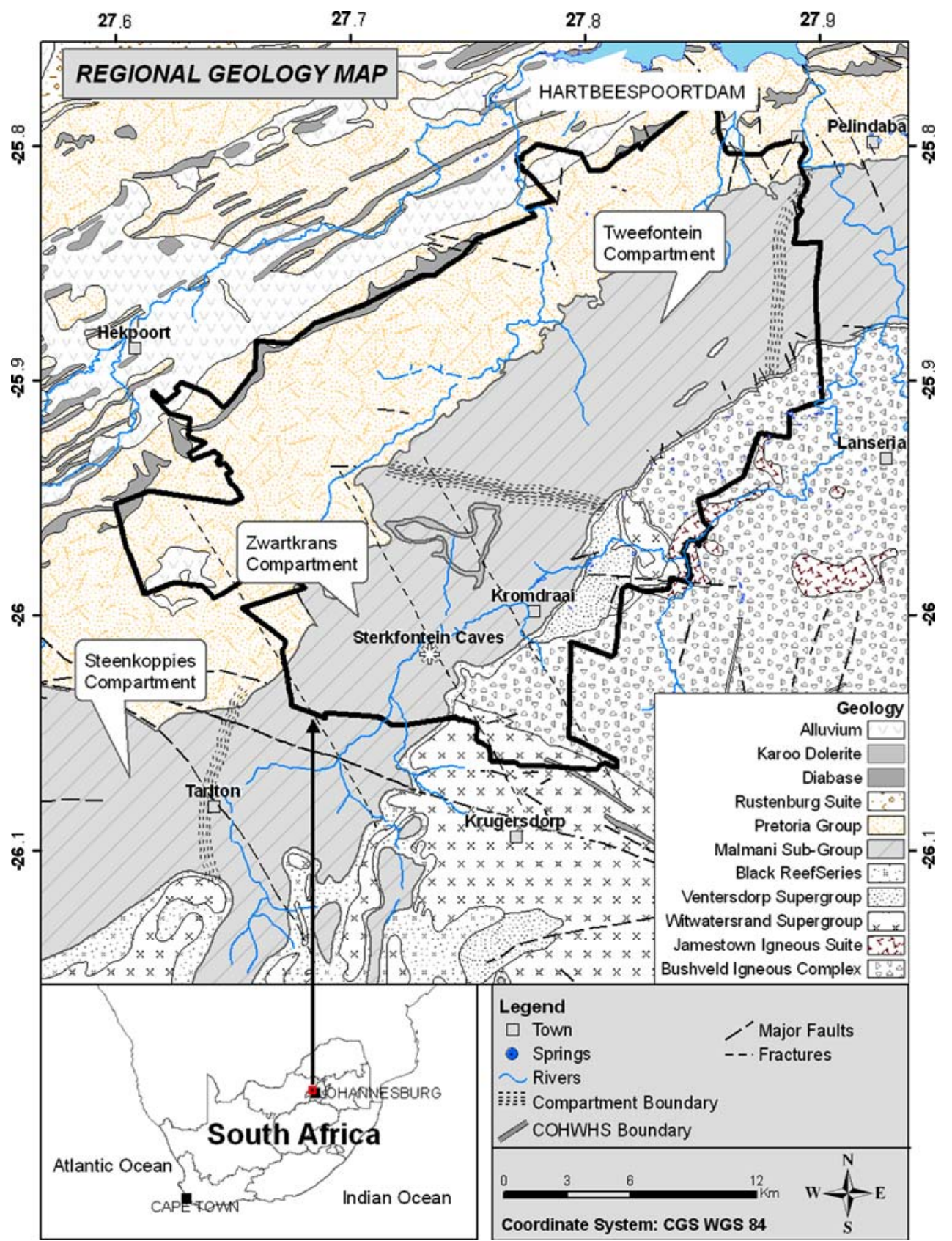

very old dolomite. Therefore, the lithologies have been subjected to deep burial, tectonisation, folding, uplifting, and prolonged episodes of natural loss of soil and rock debris in the interior of the Kaapvaal Craton. The dolomite is frequently concealed under a thick blanket of residual material that is derived from recent dolomite dissolution and the weathering of older karst regoliths. Another important and well-documented characteristic of the regional karst of the Malmani dolomite is its subdivision into 'compartments.' Dolomitic compartments are formed by the crosscutting of impervious sub-vertical dykes of dolerite and syenite, as well as by silicified faults, creating hydrogeologically isolated units with similar characteristics across that unit (Bredenkamp et al. 1986). The compartments in the study area are known as Tweefontein, Zwartkrans and Steenkoppies (Fig. 1). This investigation focuses on the more exploited Zwartkrans dolomitic compartment underlying the southern part of the COHWHS.

Climate and hydrogeology

The area experiences a sub-humid warm climate typical of the South African Highveld. The mean annual precipitation over the area varies between 600 and $700 \mathrm{~mm}$ per annum 
(DWAF 1992) and rain occurs predominantly as thunderstorms during summer, mostly between November and February.

The dolomitic formations generate little surface run-off, suggesting relatively high recharge and predominance of underground water flow, which eventually drains to springs associated with dykes, faults or formation contacts. Several perennial springs with discharges of more than $5 \mathrm{l} / \mathrm{s}$ are present in the area, but not monitored on a continual basis. Typical karst features in the area include natural springs, sinkholes, dolines and shallow depressions.

While the general groundwater flow direction (northeastwards) follows surface topography, the water levels drop sharply across dykes. The dykes act as hydraulic barriers subdividing the Zwartkrans compartment into smaller sub-compartments, with different average water levels representative for each sub-unit (Fig. 2).

In karst regions, surface-groundwater interaction becomes of major importance for the water quality when the surface water sinks into streambeds or into swallow holes. Surface drainage of the karst system is towards the NE by the Blaauwbankspruit and its tributaries (Fig. 2). The catchment has a number of anthropogenic sources that potentially influence the hydrochemistry of the karstified Zwartkrans compartment. These include the following:

1. Groundwater decanting from an abandoned mine area was pumped and treated in a modified old uranium settling plant at the time of the study. However, this facility cannot contain the amount of flow (15 Ml/day) (Van Biljon 2006) during periods of high rainfall and significant volumes of untreated polluted mine water AMD enter the Tweelopiesruit (Fig. 3).

2. The Percy Stewart and Randfontein waste water treatment plants discharge an estimated 19 and $17 \mathrm{Ml} /$ day of treated sewage effluent into the Blougatspruit and Rietspruit, respectively, which is upstream of the COHWHS (Fig. 3).

3. Animal husbandry, such as diary, poultry, feedlots and pig farming activities occur throughout the area, in addition to numerous large-scale crop productions.

The locations of these potential contamination sources in relation to the sampling points used for the assessment are given in Fig. 3.

\section{Methodology}

\section{Database preparation}

This study was carried out by combining three ground and surface water chemical datasets for the COHWHS. The first dataset was collected by the Department of Water Affairs and Forestry (DWAF) as part of the National Groundwater Database (NGDB, 1996-2007). Very few boreholes have been sampled on a continuous basis and the data are highly variable in content, reliability and periodicity of sampling. The second dataset is based on sampling conducted during 2005 by the Gauteng Department of Agriculture Conservation and Environment (GDACE). The dataset contains 56 samples retrieved from caves, boreholes, and streams throughout the karst system. The University of Pretoria (UP) sampled the source of the sewage effluent return flow, the decanting mine water as well as a number of boreholes and springs during and after the rain season (2005-2006). The water quality sampling was performed according to SABS/ISO 5667 standards and the samples were analysed in a SANAS accredited laboratory. Field measurements included $\mathrm{pH}$, electrical conductivity (EC), temperature, and dissolved oxygen content.

While the GDACE and UP samples were generally analysed for major ions ( $\mathrm{Ca}, \mathrm{Mg}, \mathrm{Na}, \mathrm{K}, \mathrm{SO}_{4}, \mathrm{Cl}, \mathrm{HCO}_{3}$, $\mathrm{NO}_{3}, \mathrm{PO}_{4}$, and $\mathrm{F}$ ) and trace elements, only selected samples captured in the NGDB were analysed for trace elements. A high percentage of trace elements values were below the analytical detection limit (censored data) and therefore not used in the multivariate analysis. Furthermore data with unacceptable errors in the charge balance $(>5 \%)$ were excluded from the database and further analysis:

$$
\begin{aligned}
& \text { Charge balance }=100 \% \\
& . \mid\left(\sum \text { cations }-\sum \text { anions }\right) /\left(\sum \text { cations }+\sum \text { anions }\right) \mid \\
& <5 \%
\end{aligned}
$$

Despite repeated sampling of the highly acidic mine drainage and analysis in different laboratories the ion balance errors remained high and the exclusion criteria was relaxed to $10 \%$ for the acid mine drainage samples. The errors are most probably related to the exclusion of protons in the charge balance (Hounslow 1995). The final dataset contained 148 samples from 47 unused, domestic and agricultural water-supply boreholes, six caves, nine springs and 24 surface water localities throughout the southern section of the COHWHS (Fig. 3).

\section{Distribution characteristics}

The distribution characteristics of each variable in the database were evaluated by histograms and their measures of location and dispersion. Since most of the applied statistical analysis assumes normally distributed data (Güler et al. 2002), a studentized range test $(n>1,000$ valid samples) for normality with a level of significance of 0.01 was performed. The studentized range test compares the ratio of the sample range and standard deviation to tabulated 


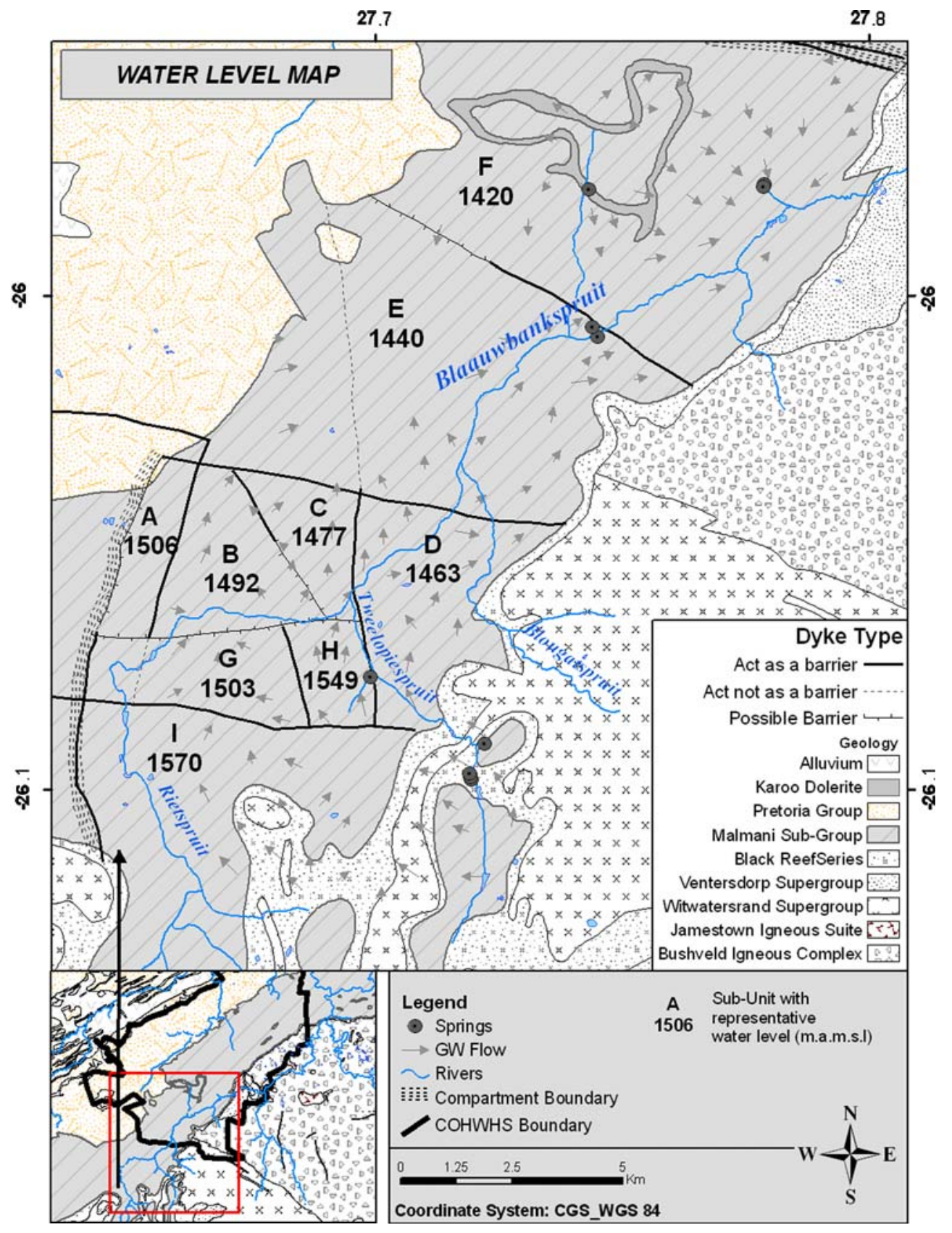

Fig. 2 Surface water drainage and groundwater flow map

critical values (Pearson and Hartley 1970). While $\mathrm{NO}_{3}, \mathrm{Cl}$, $\mathrm{Ca}, \mathrm{HCO}_{3}, \mathrm{SO}_{4}$ and $\mathrm{EC}$ follow a normal distribution, the following variables were log-transformed so they more closely correspond to a normal distribution: $\mathrm{Na}, \mathrm{K}, \mathrm{HCO}_{3}$, and $\mathrm{pH}$. These were the only variables with continuous data that could be used in the multivariate statistical analysis.

Multivariate statistical analysis

Hierarchical cluster analysis (HCA) is commonly applied to classify observations so members of the resulting groups are similar to each other but distinct from other groups (Guler et al. 2002; Heikinien et al. 2002; Hussein 2004; Lambrakis et al. 2004; Singh et al. 2004; Thyne et al. 2004). This method possesses a small space distorting effect, uses more information on cluster contents than other methods, and has been proven to be an extremely powerful grouping mechanism (Lambrakis et al. 2004). Groundwater is classified into groups, which is a different grouping from conventional geochemical graphical techniques (e.g. Piper, Schoeller and Stiff diagrams). This different grouping is mainly due to the use of a much greater combination of 
Fig. 3 Land use activities in relation to sample locations

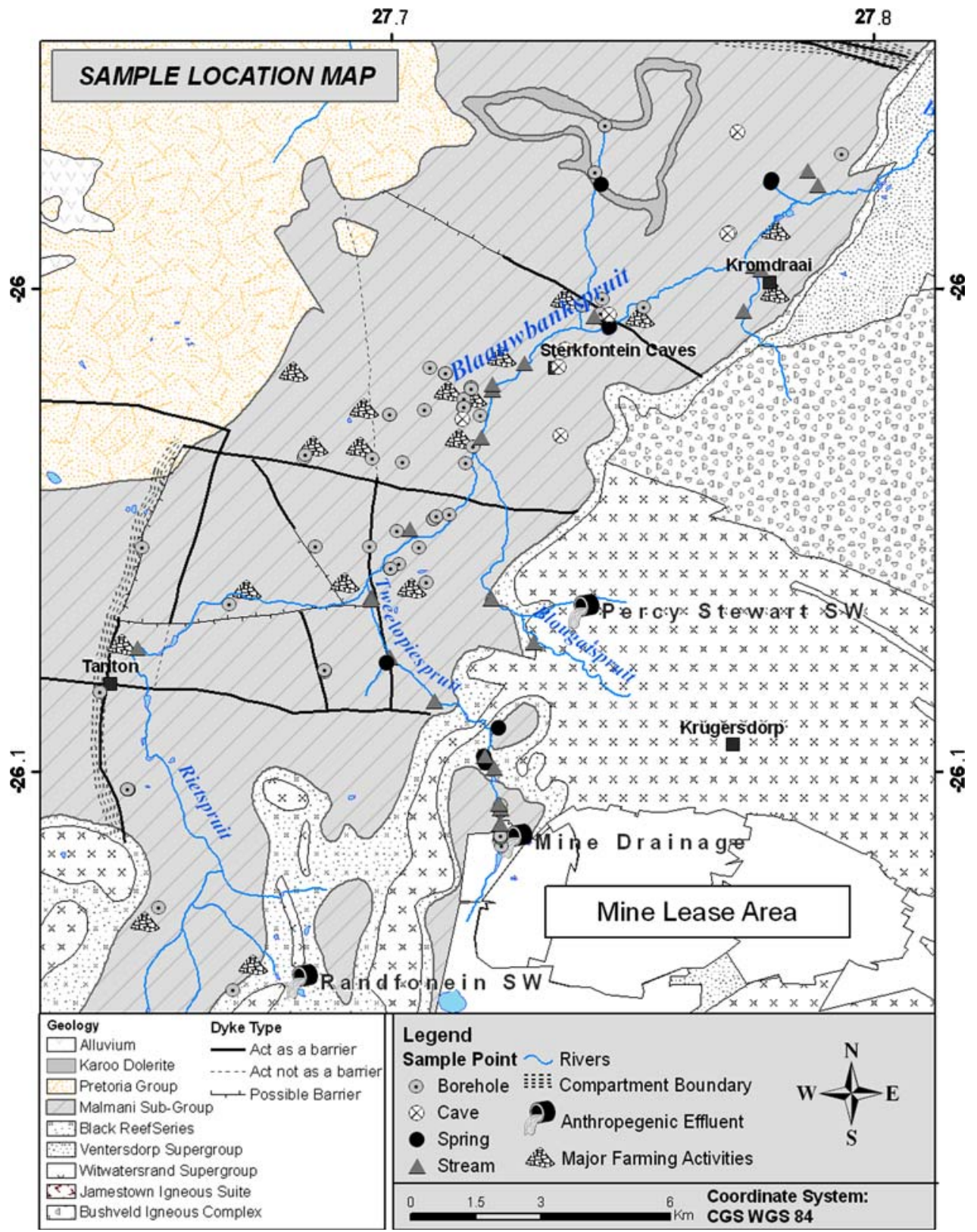

chemical and physical parameters (e.g. temperature) to classify water samples.

Ward's linkage rule was used to analyse the distances among linkages for the entire group of observations and the squared Euclidean distances were used to determine the distance between observations. The data were standardized by calculating their standard scores ( $z$-scores) as follows:

$z_{i}=\frac{x_{i}-\bar{x}}{s}$

where $z_{i}=$ standard score of the sample I, $x_{i}=$ value of sample, $\bar{x}=$ mean, $s=$ standard deviation. Standardization scales the log-transformed or raw data to a range of approximately \pm 3 standard deviations, centred about a mean of zero. Therefore, each variable has equal weight in the statistical analyses.

An HCA results in a graphical representation of the hierarchical grouping along with the corresponding rescaled distance to achieve the linkage (dendrogram). The clusters with the greatest increase in the rescaled distance are usually chosen as the final number of clusters. Cluster membership is then saved for each observation and group averages compared to the sample population average. Due to the standardization of the data for the HCA, only relative deviations from the population average may be interpreted. Mapping of cluster membership is used to spatially interpret the identified structures in the geochemical dataset (chemical signatures). 
Geochemical analysis

Plotting the chemical dataset on a Piper diagram produces a visual presentation of water types as well as of the variability and trends in the water quality of the samples. Piper diagrams or mass balance modelling might be used to estimate mixing ratios of two (or more) defined end members with relative constant (input) mass fluxes along a possible flow path. If temporal variations or analytical uncertainties of the sources/end members need to be considered, more complex mixing models (e.g. Carrera et al. 2004; Christensen et al. 2006) should be applied. In this paper, only a general mixing trend between three identified end members (two potential anthropogenic sources and pristine dolomitic groundwater) are assessed. The end members are represented by samples taken at the source of pollution itself (decanting mine shaft and treated waste water outflow) and a pristine dolomitic spring further up in the catchment. Temporal variations of the mass fluxes from these sources are assumed to be negligible and conservative transport behaviour of the selected ions sulphate and chloride, for the mass balance assumed. Geochemical modeling with PHREEQC 2.8 was used to calculate the general mixing trends as well as calcite and dolomite saturation indices for identified groundwater samples.

\section{Results and discussion}

Interpretation of cluster analysis

Based on the visual assessment of the rescaled distance in the dendrogram, three distinct hydrochemical clusters were identified (Fig. 4).

Clusters 1 and 3 are further sub-divided into two subgroups for a more comprehensive interpretation of the chemical signatures. A summary of the chemical data is presented in Table 1.

In general terms cluster 1, with the highest number of samples, is characterized by elevated sodium, chloride, bicarbonate, nitrate and sulphate concentrations, indicating the influence of a combination of anthropogenic sources. The subdivision of cluster 1 is in principal based on variations in nitrate, sulphate, chloride and bicarbonate concentrations, with SC-1a showing highly elevated nitrate chloride concentrations and SC- $1 \mathrm{~b}$ elevated concentrations of all major ions, especially sulphate.

The inclusion of all samples directly downstream of the Percy Stewart wastewater treatment plant into SC-1a suggests effluent return flows as a nitrate source. However, run-off of fertilizers and livestock excrement from the agricultural areas or domestic effluents from leaking septic tanks might contribute to the observed nitrate

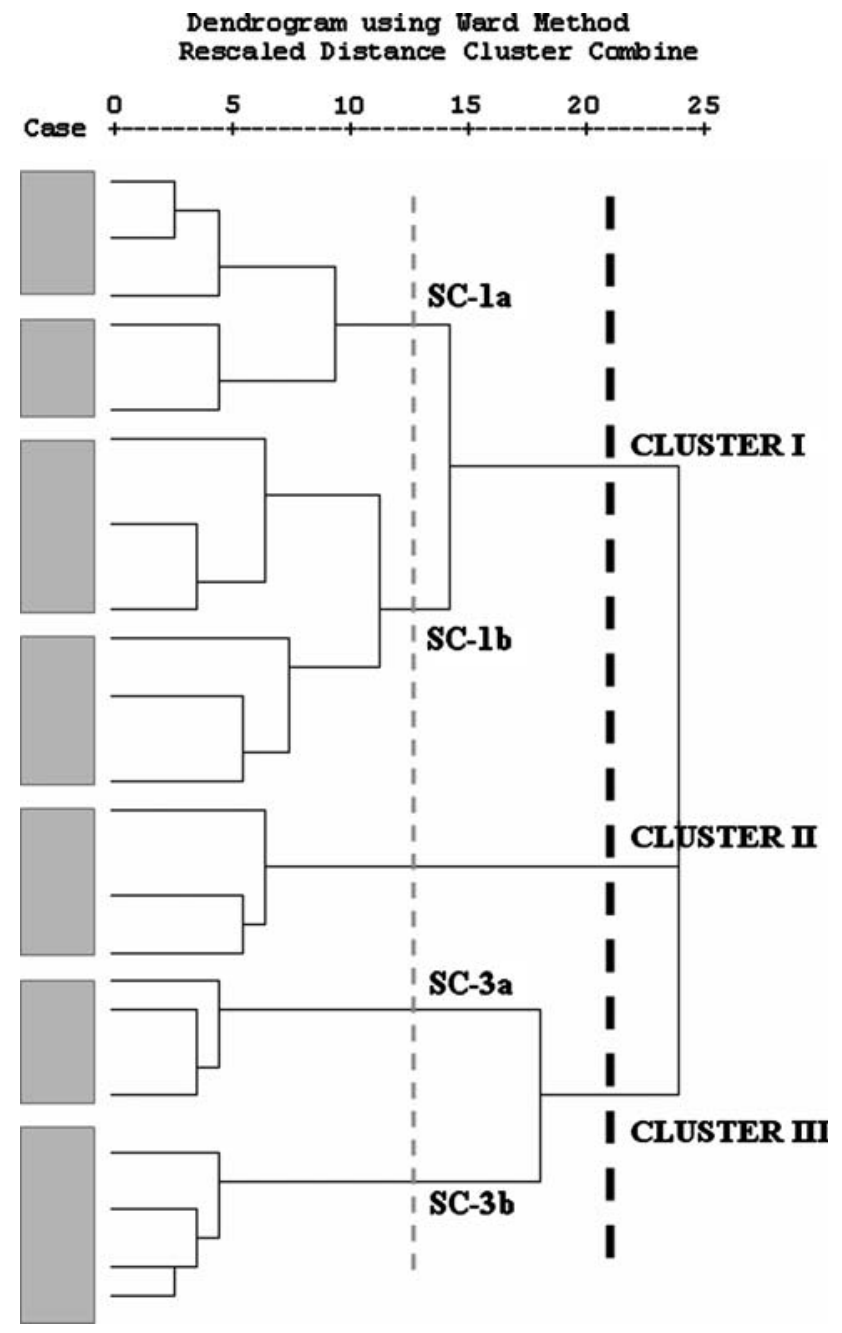

Fig. 4 HCA dendogram of the 148 water samples. Dashed vertical line defines "phenon line," which is chosen to select the number of observed clusters

concentrations. Published thresholds of nitrate concentrations indicate anthropogenic contamination range between 9 and $20 \mathrm{mg} / \mathrm{l}$ (Panno et al. 2006), indicating that this group has been severely contaminated by nitrate. The average nitrate concentration of SC-1a is within the maximum acceptable limits for drinking water in South Africa, which is $88 \mathrm{mg} / \mathrm{l}$ (7 years consumption period, SANS 2005).

Average sulphate levels of $70.5 \mathrm{mg} / \mathrm{l}$ and high coefficients of variations (up to $300 \%$ ) were measured in 223 dolomitic groundwater samples from the Chuniespoort group by Barnard (2000). Therefore, in the absence of other sulphate sources like gypsum in the dolomites, the elevated sulphate concentrations of SC- $1 \mathrm{~b} \quad(141 \mathrm{mg} / \mathrm{l})$ suggests a hydrochemical influence of the acid mine drainage on this cluster. The neutral $\mathrm{pH}$ values of cluster I samples along with high bicarbonate concentrations indicate buffering due to the dissolution of dolomite. 
Table 1 Mean values for the groups distinguished by hierarchical cluster analysis, end members highlighted

\begin{tabular}{|c|c|c|c|c|c|c|c|c|}
\hline \multirow[t]{2}{*}{ Parameter } & \multirow{2}{*}{$\begin{array}{l}\text { Complete } \\
\text { dataset }\end{array}$} & \multicolumn{3}{|c|}{ Cluster 1} & \multirow{2}{*}{$\begin{array}{l}\text { Cluster } 2 \\
\text { Total } \\
\text { group } 2\end{array}$} & \multicolumn{3}{|c|}{ Cluster 3} \\
\hline & & $\begin{array}{l}\text { Total } \\
\text { group } 1\end{array}$ & $\mathrm{SC}-1 \mathrm{a}$ & SC-1b & & $\begin{array}{l}\text { Total } \\
\text { group } 3\end{array}$ & SC-3a & $\mathrm{SC}-3 \mathrm{~b}$ \\
\hline Number of samples & 148 & 88 & 32 & 56 & 40 & 20 & 10 & 10 \\
\hline $\mathrm{pH}$ & 6.9 & 7.4 & 7.5 & 7.2 & 7.3 & 4.0 & $3.3^{\mathrm{a}}$ & 4.8 \\
\hline El. Cond $(\mathrm{mS} / \mathrm{m})$ & 111.2 & 85.0 & 87.9 & 83.4 & 34.1 & $380.3^{\mathrm{a}}$ & $491.8^{\mathrm{a}}$ & 268.7 \\
\hline $\mathrm{Na}(\mathrm{mg} / \mathrm{l})$ & 53.2 & 49.3 & 53.6 & 47.0 & 4.0 & 168.6 & 262.5 & 74.7 \\
\hline $\operatorname{Mg}(\mathrm{mg} / \mathrm{l})$ & 43.9 & 30.2 & 37.6 & 26.0 & 20.0 & 151.6 & $194.3^{\mathrm{a}}$ & $108.8^{\mathrm{a}}$ \\
\hline $\mathrm{K}(\mathrm{mg} / \mathrm{l})$ & 4.7 & 4.4 & 2.8 & 5.3 & 1.0 & 13.4 & 21.9 & 4.9 \\
\hline $\mathrm{Ca}(\mathrm{mg} / \mathrm{l})$ & 110.1 & 69.3 & 67.7 & 70.2 & 30.5 & 449.1 & $489.7^{\mathrm{a}}$ & $408.4^{\mathrm{a}}$ \\
\hline $\mathrm{HCO}_{3}(\mathrm{mg} / \mathrm{l})$ & 139.1 & 151.2 & 209.3 & 117.9 & 174.6 & 14.7 & 0.5 & 28.8 \\
\hline $\mathrm{NO}_{3}(\mathrm{mg} / \mathrm{l})$ & 19.0 & 28.0 & 54.2 & 12.9 & 6.1 & 5.6 & 9.0 & 2.1 \\
\hline $\mathrm{SO}_{4}(\mathrm{mg} / \mathrm{l})$ & 511.9 & 206.1 & 141.1 & 243.1 & 11.8 & $2858^{\mathrm{a}}$ & $4042^{\mathrm{a}}$ & $1673^{\mathrm{a}}$ \\
\hline $\mathrm{Cl}(\mathrm{mg} / \mathrm{l})$ & 34.3 & 48.7 & 63.3 & 40.4 & 4.3 & 30.5 & 33.6 & 27.4 \\
\hline
\end{tabular}

Cluster 2 combines the samples with a pristine dolomitic water signature (calcium, magnesium and bicarbonate), with all solute concentrations well within the ideal limits for drinking water in South Africa (SANS 2005).

Cluster 3 contains mostly water samples with exceptionally elevated sulphate concentrations, taken directly from or in close vicinity to the mine decanting point. The average sulphate concentration in the decanting area is about $2,858 \mathrm{mg} / \mathrm{l}$ with a $\mathrm{pH}$ value of 4.0 . This is related to the oxidation of sulphide minerals such as pyrite in the gold-bearing strata of the Witwatersrand supergroup. The relatively high $\mathrm{pH}$ value for the AMD indicates partial buffering of the acid mine drainage by the dissolution of a dolomite outlier in the decanting area itself, resulting in elevated calcium and magnesium concentrations. Consequently sulphate, calcium and magnesium concentrations as well as EC exceed the acceptable limits for drinking water in South Africa, which are 400, 150, $70 \mathrm{mg} / \mathrm{l}$ and $150 \mathrm{mS} / \mathrm{m}$, respectively (SANS 2005).

\section{Hydrochemistry}

From Fig. 5 the water chemistry in the catchment appears to evolve from a Ca-Mg to $\mathrm{Na}+\mathrm{K}$ cation predominance and from a $\mathrm{HCO}_{3}$ towards $\mathrm{SO}_{4}$ or $\mathrm{Cl}$ anion predominance. The direction of these trends is consistent with increasing specific conductance and total dissolved solid content of the samples towards potential sources. The $\mathrm{Ca}-\mathrm{Mg}-\mathrm{SO}_{4}$ facies samples in the upper corner of the diamond are influenced by acid mine drainage and represent the highly mineralized water samples combined in cluster III of the HCA.

The samples in the left corner of the diamond $(\mathrm{Ca}-\mathrm{Mg}-$ $\mathrm{HCO}_{3}$ facies) represent cluster 2, i.e. pristine dolomitic water not impacted by anthropogenic sources.

Wastewater treatment return flow samples, as well as downstream surface water samples, plot towards the right corner of the diamond ( $\mathrm{Na}-\mathrm{Cl}$ facies) and were grouped into cluster 1 . The water samples have an equivalent mole ratio of $\mathrm{Na} / \mathrm{Cl}$ larger than one, clearly deviating from ratios determined by Galloway et al. (1983) for Atlantic rainwater (0.81-0.90) or seawater (0.86). In the absence of chloride bearing strata and based on observed high chloride concentrations at the outlet and downstream of the waste-water treatment plants, the distinctively elevated chloride concentrations were related to wastewater treatment return flows. Diffuse agricultural/irrigation return flows contribute to the salt load as well, but were in the absence of known concentrations not considered in the geochemical modelling.

The majority of the samples plot in the Piper diagram between these three extreme end members (acid mine drainage, pristine dolomite water and waste water treatment return flows). A potential mixing field between the end members was modelled with PHREEQC 2.8 by varying mixing ratios of two consecutive end members. It is important to note that fluid-rock interactions (e.g. dolomite dissolution), reactive transport, as well as influences of agricultural land use practices were neglected in the calculations. While the majority of observed variations in the anion ratios of the water samples are relatively welldescribed with such simplified mixing trends between the three end members, the cation ratios of the water samples show significant deviations from the conservative mixing calculations. The observed curved trend towards the sodium apex in the Piper plot suggests for example ion exchange as another important, non-negligible process along the flow path.

Therefore, the chosen approach only shows the potential to describe observed chemistry changes by simple mixing of three sampled end members. Source apportioning for individual boreholes or springs should be done with inverse geochemical modelling considering reactions along the 
Fig. 5 Piper diagram presenting the composition of groundwater and surface water samples. Mixing calculation trend lines is shown on the Piper diagram

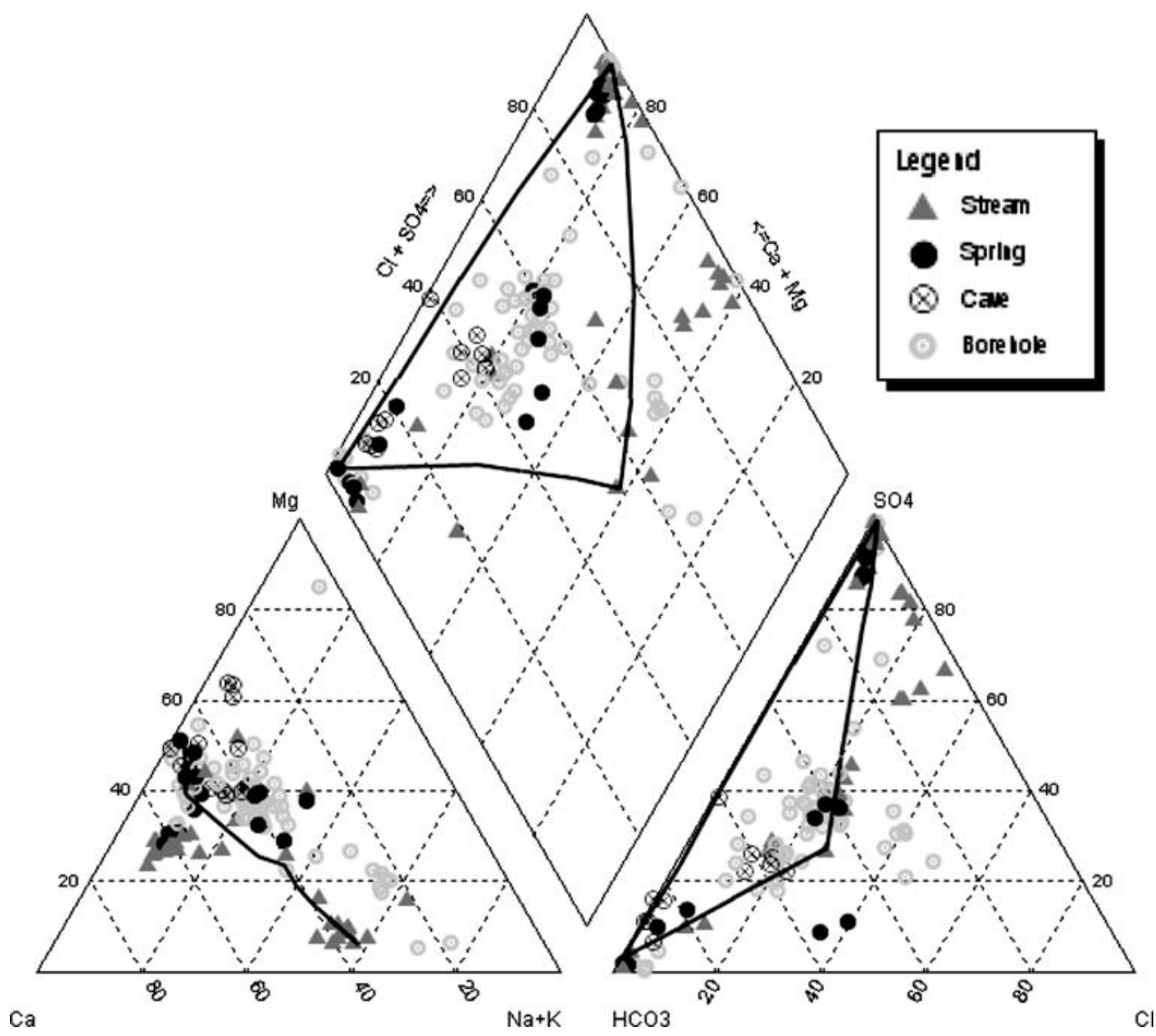

flow path or e.g. multivariate receptor models (Christensen et al. 2006) to allow uncertainties and variations in the source concentrations.

\section{Spatial distribution}

The relationship of the statistically defined clusters of samples to geographic location illustrates the most important information that geochemical survey datasets contain, i.e. the variation in regional distribution (Reimann et al. 2005). Mapping the cluster groups based on their chemical similarity allowed us to identify the spatial relationship of hydrochemical processes and/or flow paths.

Based on the spatial distribution map (Fig. 6) it is evident that cluster 3 indicates samples taken at the source of the acid mine drainage. Cluster 1 and its subgroups represent the contamination signature and are located either in the immediate vicinity of the anthropogenic sources or along the flow path of polluted surface waters. A look at the cluster distributions map reveals that SC-1a shows some correlation with agricultural land use practice and $\mathrm{SC}-1 \mathrm{~b}$ indicates the contamination signature from either the mine drainage or the waste water return flows (Fig. 6). Cluster 2 represents the natural water of the dolomite and is either located beyond the current area of anthropogenic influence or related to the mixing (dilution) of surface water and groundwater of uncontaminated flow paths.

To the west of the main north-west transecting dyke (Sub-unit B \& H) a number of samples represent the background water composition (cluster 2), whereas the samples towards the east of the dyke indicate the contaminant signature (SC-1b). The SE-NW striking dyke towards the northeast (Sub-unit F) acts also as a hydrogeological barrier. The contamination signature of SC-1b in sub-unit $\mathrm{F}$ is possibly occurring via surface flow paths from sub-unit E, before it enters the underground water network via streambed leakage. Water samples taken from caves along the contamination flow paths indicate pristine waters (cluster 2) suggesting that these caves occur as stacked perched water tables, which was also illustrated by Jamison et al. (2004). The chemical contents, saturation indexes and simple mixing ratios of groundwater samples identified from SC-1b and along the Blaauwbankspruit are given in Table 2.

The mixing ratios in Table 2 confirm a general trend of decreasing contributions of the respective source (AMD and Percy Stewart) along the flow paths (Fig. 6), with minor contributions of AMD and major influences of effluent return flows being already evident in sub-unit $\mathrm{F}$ (Table 2, Bol 01 and DUP1). However, since the additional 
Fig. 6 Spatial distribution of the hydrochemical clusters identified by the HCA

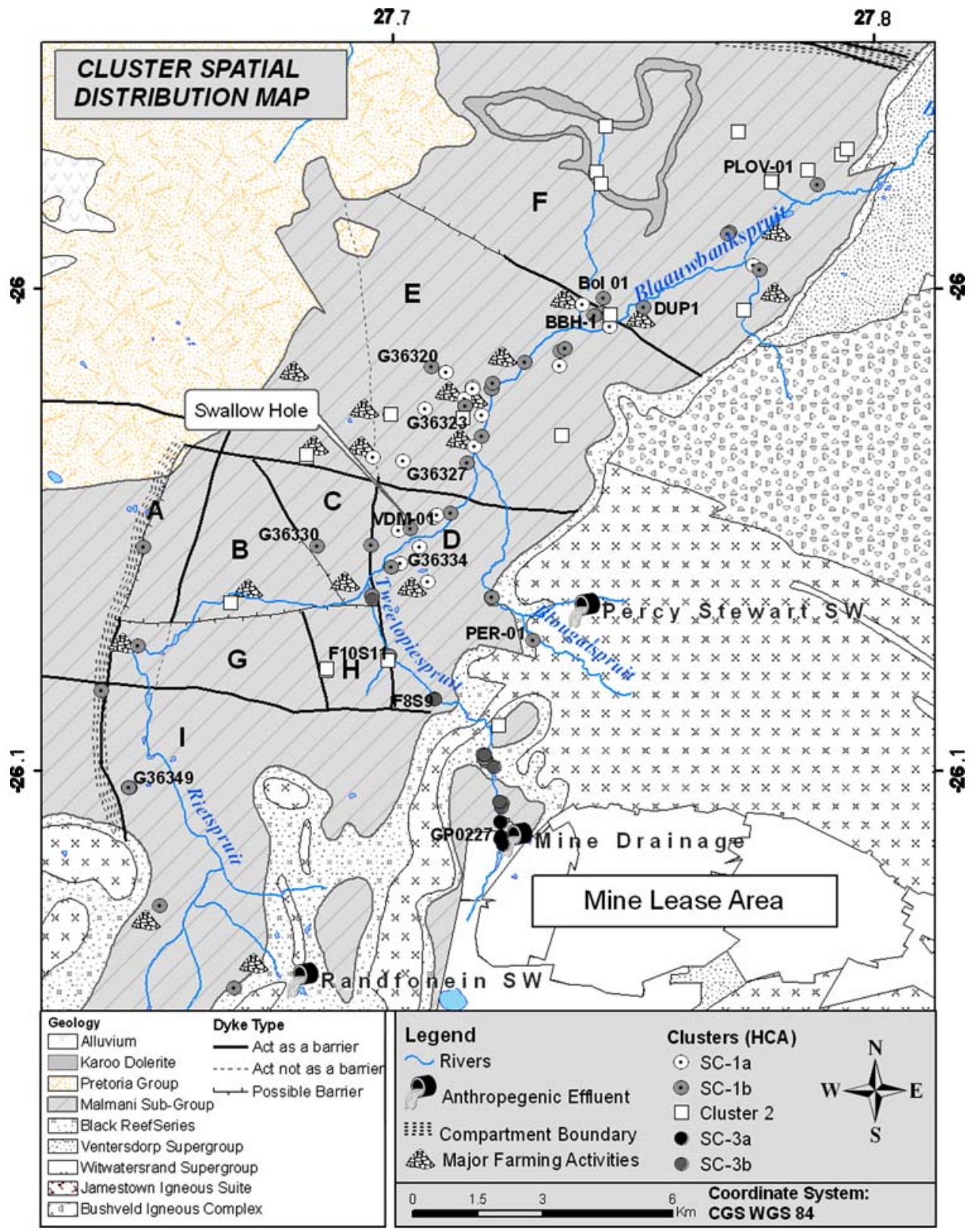

chloride loads from diffuse agricultural or irrigation flows were not considered in the simple end-member mixing analysis, the Percy Stewart SW ratios serve only as an upper limit. Detailed source apportioning using e.g. multivariate receptor models to account for the variability and co-linearity of the different sources needs to be done.

\section{Conclusion}

The combination of statistical, spatial, geochemical and end-member analysis provides useful assessment of controls over water composition and assists in the identification of possible anthropogenic influences. The methodology integrates the information from each technique producing a more robust interpretation. The procedures outlined here may assist in hydrogeological characterization, contaminant plume delineation, and future monitoring designs. Deterioration in groundwater and surface water quality were observed downstream of a mine water discharge area and wastewater treatment works. The dominant water facies in the study area changed due to infiltration of polluted water from a $\mathrm{Ca}-\mathrm{Mg}-\mathrm{HCO}_{3}$ type to a $\mathrm{Mg}-\mathrm{Ca}-\mathrm{SO}_{4}$ or $\mathrm{Na}-\mathrm{SO}_{4}$ type. The geochemical processes responsible for the variation in groundwater quality are mixing, ion exchange and mineral dissolution. The dendrogram of cluster analysis identified the existence of three hydrochemical regimes. These statistical groups have distinct spatial patterns in the 
Table 2 Geochemical analysis (in mg/l) and mixing calculations based on a simple sulphate and chloride mass balance of groundwater samples

\begin{tabular}{|c|c|c|c|c|c|c|c|c|c|c|}
\hline \multirow{2}{*}{$\begin{array}{l}\text { Flow path } \\
\text { (sample number) }\end{array}$} & \multirow[t]{2}{*}{$\mathbf{N a}$} & \multirow[t]{2}{*}{ Mg } & \multirow[t]{2}{*}{$\mathbf{K}$} & \multirow[t]{2}{*}{$\mathbf{C a}$} & \multirow[t]{2}{*}{$\mathrm{NO}_{3}$} & \multirow[t]{2}{*}{$\mathrm{SO}_{4}$} & \multirow[t]{2}{*}{ Cl } & \multirow[t]{2}{*}{ Mixing ratio ${ }^{\mathrm{a}}$} & \multicolumn{2}{|c|}{ Saturation indexes } \\
\hline & & & & & & & & & Calcite & Dolomite \\
\hline GP0227 & 98.4 & 228.2 & 14.7 & 515.9 & 3.4 & 4512.5 & 40.0 & $(1: 0: 0)$ & -4.280 & -8.539 \\
\hline F8S9 & 46.3 & 51.1 & 3.3 & 185.3 & 3.8 & 809.9 & 19.7 & $(0.18: 0.13: 0.70)$ & -1.070 & -2.368 \\
\hline F10S11 & 29.5 & 38.0 & 1.9 & 130.0 & 4.0 & 530.4 & 17.5 & $(0.11: 0.13: 0.76)$ & -0.115 & -0.431 \\
\hline F11S12 & 28.2 & 40.8 & 1.7 & 123.4 & 3.0 & 478.6 & 14.5 & $(0.10: 0.10: 0.80)$ & -0.264 & -0.674 \\
\hline PER-01 & 104.0 & 7.0 & 20.0 & 64.0 & 0.9 & 123.0 & 94.0 & $(0: 1: 0)$ & 0.254 & -0.112 \\
\hline G36349 & 53.0 & 11.2 & 1.8 & 19.9 & 15.8 & 63.7 & 61.4 & $(0: 0.65: 0.36)$ & -0.7798 & -1.4664 \\
\hline G36330 & 18.0 & 16.0 & 0.9 & 26.0 & 0.4 & 52.0 & 24.0 & $(0: 0.25: 0.75)$ & -0.6443 & -0.9911 \\
\hline VDM-01 & 10.7 & 18.4 & 2.0 & 32.9 & 5.4 & 37.0 & 16.4 & $(0: 0.16: 0.84)$ & 0.0708 & 0.2382 \\
\hline G36334 & 35.6 & 41.1 & 1.9 & 54.1 & 30.8 & 201.4 & 54.3 & $(0.03: 0.56: 0.41)$ & -0.6443 & -0.9911 \\
\hline G36327 & 44.0 & 34.0 & 1.4 & 61.0 & 11.94 & 79.0 & 58.0 & $(0: 0.61: 0.39)$ & -0.1186 & -0.1020 \\
\hline G36323 & 47.0 & 40.0 & 2.0 & 71.0 & 18.2 & 106.0 & 54.0 & $(0.01: 0.57: 0.42)$ & 0.507 & 1.136 \\
\hline G36320 & 36.0 & 37.0 & 1.0 & 56.0 & 13.3 & 82.0 & 47.0 & $(0: 0.49: 0.51)$ & 0.0697 & 0.3061 \\
\hline BBH-1 & 25.6 & 37.9 & 0.9 & 58.0 & 39.3 & 111.0 & 34.1 & $(0.01: 0.35: 0.64)$ & -0.0988 & -0.0368 \\
\hline Bol 01 & 29.4 & 32.5 & 0.5 & 67.2 & 32.9 & 126.0 & 46.9 & $(0.01: 0.48: 0.49)$ & 0.8288 & 1.6896 \\
\hline DUP1 & 46.0 & 28.0 & 1.4 & 48.0 & 10.6 & 114.0 & 56.0 & $(0.01: 0.59: 0.41)$ & -0.6544 & -1.1988 \\
\hline PLOV-01 & 1.7 & 24.7 & 0.25 & 37.7 & 1.7 & 2.9 & 1.6 & $(0: 0: 1)$ & -0.1376 & -0.1082 \\
\hline
\end{tabular}

a Indicates mixing ratio's of the three identified end-members (AMD, Sewage Works and Pristine dolomite) based on $\mathrm{SO}_{4}$ and $\mathrm{Cl}_{\text {mass }}$ balance ratios

Bold values indicate identified end-members

study area, providing the spatial discrimination desired when determining hydrochemical facies. According to the analysis, large portions of the karst aquifer are affected by recharge from tributaries carrying pollutants from acid mine drainage and treated sewage effluent. Inflows into the system occur via swallow holes and leakage through the riverbed. The groundwater flow paths themselves are influenced by the compartmentalization of the karst aquifer, which contain the contaminate plume in certain areas, although surface waters transport pollutants from one groundwater compartment to the next.

The results showed areas that have water chemistry due to natural water-rock interactions (pristine dolomitic water) while other areas were highly impacted by anthropogenic sources. The best indicators for the present pollution in the dataset are elevated electrical conductivity and increased concentrations of sulphate, chloride and nitrate, all of which are easy to monitor. The greatest risk to the use of the groundwater resource is related to the polluted acid mine drainage, with ion concentrations exceeding the recommended values for drinking water in South Africa considerably.

Acknowledgments The authors would like to thank the anonymous reviewers for their detailed and thoughtful comments on earlier versions of this manuscript.
Open Access This article is distributed under the terms of the Creative Commons Attribution Noncommercial License which permits any noncommercial use, distribution, and reproduction in any medium, provided the original author(s) and source are credited.

\section{References}

Barnard H (2000) An explanation of the 1:50,000 general hydrogeological map. DWAF, Pretoria

Bredenkamp DB, Van der Westhuizen C, Wiegmanns FE, Kuhn CM (1986) Groundwater supply potential of dolomite compartments west of Krugersdorp. Technical report Gh3440. DWAF, Pretoria

Carrera J, Vázquez-Suñé E, Castillo O, Sánchez-Vila X (2004) A methodology to compute mixing ratios with uncertain endmembers. Water Resour Res 40:w12101

Christensen WF, Schauer JJ, Lingwall JW (2006) Iterated confirmatory factor analysis for pollution source apportionment. Environmetrics 17:663-681

Clendennin CW (1989) Tectonic influence on the evolution of the early Proterozoic Transvaal sea, Southern Africa. PhD Thesis, Wits University, Johannesburg

Department of Water Affairs, Forestry (1992) Hydrology of the upper Crocodile river sub-system. Report Nr. PA200/00/1492. vol I \& II, DWAF, Pretoria

Doctor DH, Alexander CE Jr, Petrič M, Kogovsek J, Urbanc J, Lojen S, Stichler W (2006) Quantification of karst aquifer discharge components during storm events through end-member mixing analysis using natural chemistry and stable isotopes as tracers. Hydrogeol J 14:1171-1191 
Galloway JN, Knap AH, Church TM (1983) The composition of western Atlantic precipitation using shipboard collectors. J Geophys Res 88:10859-10864

Glynn PD, Plummer NL (2005) Geochemistry and the understanding of ground-water systems. Hydrogeol J 13:263-287

Güler C, Thyne GD, McCray JE, Turner AK (2002) Evaluation of graphical and multivariate statistical methods classification of water chemistry data. Hydrogeol J 10:455-474

Heikkinen PM, Korkka-Niemi K, Lathi M, Salonen VP (2002) Groundwater and surface water contamination in the area of the Hitura nickel mine, western Finland. Environ Geol 42:313-329

Hobbs PJ, Cobbing JE. 2007. A Hydrogeological Assessment of Acid Mine Drainage Impacts in the West Rand Basin, Gauteng Province. Report no. CSIR/NRE/WR/ER/2007/0097/C. CSIR/ THRIP, Pretoria

Hounslow AW (1995) Water quality data: analysis and interpretation, CRC Press, New York

Helena B, Pardo R, Vega M, Barrado E, Fernandez JM, Fernandez L (2000) Temporal evolution of ground water composition in an alluvial aquifer (Pisuerga river, Spain) by principal component analysis. Water Res 34:807-816

Hussein MT (2004) Hydrochemical evaluation of groundwater in the Blue Nile basin, eastern Sudan, using conventional and multivariate. Hydrogeol J 12:144-158

Jamison AA, Van Niekerk EJ, Viljoen MJ 2004. Bedding-parallel, shear \& sinistral wrench faulting influencing location and formation of caves in the Cradle of Humankind, Gauteng. Ext. Abs Geocongress 2004. GSSA

Lambrakis N, Antonakos A, Panagopoulos G (2004) The use of multicomponent statistical analysis in hydrogeological environmental research. Water Res 38:1862-1872

Love D, Hallbauer D, Amos A, Hranova R (2004) Factor analysis as a tool in groundwater quality management: two southern Africa case studies. Phys Chem Earth 29:1135-1143
McNeil VH, Malcolm EC, Preda M (2005) Assessment of chemical water types and their spatial variation using multi-stage cluster analysis, Queensland, Australia. J Hydrogeol. doi:10.1016/ j.jhydrol.2004.12.014

Panno SV, Kelly WR, Martinsek AT, Hackley KC (2006) Estimating background and threshold nitrate concentrations using probability graphs. Groundwater 44:697-709

Pearson AV, Hartley HO (1970) Biometrica tables for statisticians, vol 1. Cambridge University, Cambridge

Reimann C, Filzmoser P, Garrett RG (2005). Background and threshold: critical comparison of methods of determination. Sci Total Environ 346:1-16

SANS (2005) South African national standard (241) drinking water, 6th edn. South Africa

Singh KP, Malik A, Mohan D, Sinha S (2004) Multivariate statistical techniques for the evaluation of spatial and temporal variations in water quality of the Gomti river (India) - a case study. Water Res 38:3980-3992

Thyne G, Güler C, Poeter E (2004) Sequential analysis of hydrochemical data for watershed characterization. Groundwater 42:1-12

Van Biljon M (2006) Geo-hydrogeological review of the potential impact on the Sterkfontein dolomite during increased surface water run-off. Rison Groundwater Consulting, Krugersdorp

Wang Y, Ma T, Luo Z (2001) Geostatistical and geochemical analysis of surface water leakage into groundwater on a regional scale: a case study in the Liulin karst system, north-western China. J Hydrogeol 246:223-234

Williams TM, Smith B (2000) Hydrochemical characterization of acute acid mine drainage at Iron Duke Mine, Mazowe, Zimbabwe. Environ Geol 39:272-278 